PF 2019 (LXXIV): 207-212

\author{
PAVOL ŽIGO \\ Katedra slovenského jazyka \\ Filozofická fakulta Univerzity Komenkého \\ Gondova ul. 2 \\ 81499 Bratislava \\ tel. +421 259339445 \\ e-mail: pavol.zigo53@gmail.com
}

\title{
POMENOVANIE MANŽELKINHO BRATA (NIELEN) V SLOVENSKÝCH NÁREČIACH
}

KLÚČOVÉ SLOVÁ: Slovanský jazykový atlas, nomina afinitatis, narúšanie sterotypov, interkultúrny kontakt.

SŁOWA KLUCZOWE: Ogólnosłowiański atlas językowy, nomina afinitatis, naruszenie stereotypów, kontakt międzykulturowy.

KEYWORDS: : Slavic Linguistic Atlas, nomina afinitatis, expression of kinship, intercultural contact.

\section{THE NAME OF THE WIFE'S BROTHER (NOT ONLY) IN SLOVAK DIALECTS}

\begin{abstract}
A significant feature of terminology describing family relations in Slavic languages is its substantial cognitive value from the linguistic and extra-linguistic point of view. They reflect not only internal language development, but also mainly extralinguistic factors that give the possibility to identify the cultural development context in space and time. The author's focus is on the development of two groups of words relating to kinship acquired by marriage - nomina afinitatis. The first group of words naturally - is characterized by integration tendencies with other Slavic languages, while the second group shows a divergent tendency which is characterized by a decline of the original Slavic name system, e. g. šur, dever, svojak, zolva/zelva etc. and borrowing of words of German origin like švagor/švagriná without regard to the respective relationship to bride or bridegroom, or to their parents.
\end{abstract}


Slovanský jazykový atlas, v ktorom významnú a dlhodobú rolu pri interpretácii vývinu, distribúcie a súčasných podôb slovnej zásoby a medzijazykových kontaktov zohráva náš jubilant, je presvedčivým vysoko hodnotným medzinárodným projektom, poukazujúcim na podstatu vývinu a súčasný stav prirodzených podôb slovanských jazykov v jednotlivých areáloch. Zároveň je aj indikátorom medzijazykových kontaktov, interkultúrnych vplyvov a vývinu spoločenských formácí́, ktoré po stáročia vplývali na hospodársku a duchovnú oblast' Slovanov. Velké množstvo týchto vysoko hodnotných poznatkov tvorí obsah desiatok vedeckých štúdií, najmä syntetizujúcich monografií Janusza Siatkowského, ku ktorým sa v posledných rokoch zaradili tituly Studia nad wplywami obcymi w ogólnosłowiańskim atlasie językowym (Warszawa 2004), Słowiańskie nazwy wykonawców zawodów w historii i dialektach (Warszawa 2005), Słowiańskie nazwy ciała w historii i dialektach (Warszawa 2012), Studia nad słowiańsko-niemieckimi kontaktami jezzykowymi (Warszawa 2015), najnovšie aj monografia Pogranicze polsko-wschodniosłowiańskie. Studia wyrazowe v spouautorstve s D.K. Rembiszewskou (Warszawa 2018), a množstvo d’alších štúdií. Precízna analýza praslovanskej lexiky, identifikácia medzijazykových vztahov Slovanov s neslovanskými etnikami a ich jazykmi v konfesionálnej, administratívno-právnej, ekonomickej aj hospodárskej sfére vyústila $v$ týchto tituloch do vysoko fundovanej historicko-jazykovednej argumentácie, spočívajúcej na metodologickej rovnováhe, rešpektujúcej autochtónne slovanské aj prevzaté - neslovanské lexikálne prvky. Tieto práce poskytujú velké množstvo poznatkov, odkrývajúcich d’alšie možnosti interpretácie prirodzeného vývinu slovanských jazykov a identifikácie adaptačných procesov slov nedomáceho pôvodu v slovanskom jazykovom prostredí. Účast' J. Siaktowského v morfonologickej sekcii Slovanského jazykového atlasu, v ktorej minuncióznou presnostou identifikuje východiskové podoby kartografovaných lexém či hláskoslovných javov, je na každej mape tohto projektu vyčerpávajúcim obrazom špecifických podôb $\mathrm{v}$ jednotlivých areáloch. Týmito našimi riadkami nechceme suplovat interpretáciu tejto zložky Slovanského jazykového atlasu, ale chceme nimi poukázat na jeho mnohoaspektovost'. Jeho riešitelom a autorom je všeobecne známa skutočnost', že terénny heuristický materiál, ktorý tvorí súčast' projektu, a jeho kartografické spracovanie nie sú definitívnym záverom problematiky. Aj preto, že rozsiahly nárečový materiál celoslovanského územia dáva na pozadí kartografického spracovania možnost̉ jeho dalšej integrácie s poznatkami etnologickej, historickej či kulturologickej povahy, a to práve tým, že historicko-jazykovedne interpretované javy sú prostriedkom identifikácie jazykového vývinu v kontaktoch, ktoré sa odrážajú v súčasnej prirodzenej podobe slovanských jazykov, i ch nespisovných - a celkom prirodzene aj spisovných - podobách.

$Z$ velkého množstva javov $z$ územia všetkých slovanských jazykov možno ako vybraný príklad v prirodzených jazykových útvaroch uviest’ formy vyjadrovania 
príbuzenských vztahov, ktoré vznikli vydajom alebo ženbou Slovanov (nomina afinitatis). Naše riadky vnímame ako návrat $\mathrm{k}$ tematike, ktorú sme pred časom spracúvali na úrovni medzijazykových kontaktov (Žigo, Žigová 1987, Žigo 2010) a dopĺname ju čiastkovými poznatkami z revízie materiálu Slovanského jazykového atlasu s tažiskom na nerovnorodost' jazykového a kultúrneho prostredia.

$\mathrm{V}$ pomenovaní rodinných vztahov, ktoré vznikli vydajom alebo ženbou, t. j. vo významovej skupine nomina afinitatis používali starí Slovania na pomenovanie manželovho brata výraz dever (psl. * “ěverb). Toto slovo sa v starších prameňoch zachovalo vo význame 'zatov brat', 'manželov brat', 'prvý družba' (Majtán 1991: 248). Manželkinho brata tradične starí Slovania pomenúvali slovom šur (psl. * ̌̌urb), manžel manželkinej sestry sa pomenúval slovom svojak (psl. ${ }^{*}$ svojbakz), sestrin manžel sa pomenúval výrazom zat' (psl. $\left.{ }^{*} z e ̨ t b\right)$ a mal význam 'priženený, aby zachoval rod', z neho sa vyvinul dnešný význam 'dcérin manžel'. Manželova sestra sa pomenúvala slovom psl. ${ }^{\star} z e l v a,{ }^{\star} z o l v a$ a znamenalo doslovne ‘žena, ktorá sa vydala do rodiny svojho manžela', $v$ rovnakom význame je z južnoslovanských jazykov známe slovo jetrva. Potomkovia súrodencov sa pomenúvali na pozadí spoločného rodu, plemena, derivátmi východiskového praslovanského základu *pelmę vo význame 'patriaci do jedného rodu, plemena', a to aj v prechýlených podobách ženského rodu (porovnaj s dnešnou podobou племянница), významovo zodpovedajúce výrazu neter (psl. $\left.{ }^{\star} n e p t-i j o,{ }^{\star} n e t b j b\right)$.

Pôvodná praslovanská sústava príbuzenských pomenovaní sa na území dnešného Slovenska pod vplyvom kontaktov s inojazyčným etnikom oslabila a prispôsobila sa pomenovacej sústave nemčiny. Dokazuje to vývin, v dôsledku ktorého sa germanizmy švagor na celom území slovenských nárečí ustálili na pomenovanie manželovho brata (pôvodne * děverb vo význame 'manželov brat' aj 'prvý družba') aj manželkinho brata (pôvodne `šurb aj vo význame kolektíva, t. j. 'vlastní bratia mojej manželky'), manžela manželkinej sestry ( ${ }^{*}$ svojbakz 'patriaci do našej rodiny, vlastný príbuzný), aj sestrinho manžela (pôvodne ${ }^{*} z e ̨ t b ~ ' p r i-$ ženený, aby zachoval rod'). Prechýlená podoba švagriná sa tak isto na celom slovenskom jazykovom území ustálila na pomenovanie manželovej sestry (pôv. ‘zelva, 'zolva 'žena vydatá do rodiny svojho manžela') aj bratovej manželky (nevestka 'privedená do rodiny svojho manžela'). Táto zjednodušená pomenovacia sústava rodinných príslušníkov vyníma slovenčinu a ostatné západoslovanské jazyky, ktoré boli pod rímskym konfesionálnym vplyvom z pôvodného byzantsko-slovanského typu nomina afinitatis tej istej generácie a integruje ich lexémami neslovanského, nemeckého pôvodu (der Schwager / die Schwägerin). Presah tejto lexémy je aj do madarčiny v podobe sógor, odkial sa kontaktom rozšírila aj do malej časti srbských a chorvátskych nárečí.

Výsledkom interkultúrnych a medzijazykových kontaktov slovanského obyvatel'stva $s$ inojazyčným etnikom románskeho pôvodu sa $\mathrm{v}$ obchodno-cestova- 




Heterogénnosṫ západoslovanského a južnoslovanského areálu manželkinho brata v slovanskom areáli. Vo východoslovanskom areáli sa zachoval pôvodný lexikálny základ šur-.

tel'skom prostredí jadranského pobrežia stalo pomenovanie manželkinho brata formou kuňot, vychádzajúce $\mathrm{z}$ románskeho jazykového základu, najpravdepodobnejšie prostredníctvom taliančiny z pôvodného cōgnātus 'pokrvný príbuzný', resp. 'podobný, zhodný. V tomto prípade došlo pravdepodobne k významovému posunu od významu 'pokrvný príbuzný' smerom k významu 'spoznaný spolu s mojou manželkou', resp. 'prostredníctvom nej'). Vo východnej časti bulharského jazykového územia sa pod vplyvom turečtiny s odlišným konfesionálnym vplyvom stabilizovali podoby, vychádzajúce z formy kadžinbirader do adaptovanej formy kainč. Základné areály týchto vybraných vplyvov ilustrujeme len 
schematicky na časti materiálu Slovanského jazykového atlasu, ktorého komplexná interpretácia tvorí náplň pripravovaného samostatného zväzku v redakcii bulharskej národnej komisie.

Areálová distribúcia jednotlivých foriem pomenovania manželkinho brata skrýva v sebe velmi silný interkultúrny fenomén. Naznačili sme ho v rámci vplyvu odlišnej konfesionálnej situácie v niekolkých lokalitách východnej časti bulharských nárečí. Pohlad na rozsiahly celoslovanský areál je však svedectvom širšieho historicko-spoločenského kontextu na jazykový vývin. Podoby švagor - v rozličných hláskoslovných variantoch, odrážajúcich typické zákonitosti jednotlivých jazykov - nevyjadrujú len vplyv nemeckého jazykového kontaktu so slovanským obyvatel'stvom, ale sú dôkazom duchovného a jazykového vplyvu na areál, ktorý sa ocitol pod vplyvom rímsko-katolíckej konfesie. Ako je známe, konfesionálne prostredie - stará horná nemčina - bola prostriedkom prenikania stredovekých latinizmov smerom na východ od nemecky hovoriacich krajín. $\mathrm{Na}$ tom slovanskom jazykovom území, kde sa zachoval výrazný vplyv pôvodného byzantského rítu, preto dodnes ostali súčastou pomenovacej sústavy rodinných vztahov východiskové lexémy pôvodnej slovanskej sústavy nomina afinitatis.

Osudy pomenúvana rodinných vztahov v triede nomina afntatis sú dôkazom racionálne riadeného orientačného správania, ktoré vychádza z prvotných analogických nadinštinktívnych reakcií v rámci uvedomovania si generačného a afinitného príbuzenského vztahu. Procesy, výsledkom ktorých je súčasný stav, nespočívali na imitácii, na zámernom napodobňovaní okolia, ale sú dôsledkom formovania sa odlišnej kognitívnej podstaty. Tieto procesy sú z hladiska vývinu jazyka ireverzibilné a dominuje $\mathrm{v}$ nich kognitívna asimilácia, ktorej podstatou je, že používaním pôvodne neznámej formy sa pod vplyvom interlingválnych kontaktov umocnených konfesiou oslabuje pôvodný stav až do takej miery, že geneticky pôvodný prvok časom ustúpi. Dôkazom je skutočnost', že nikto z používatelov súčasného slovenského jazyka - okrem etymológov a časti historických jazykovedcov a dialektológov - dnes už v prirodzených jazykových útvaroch slovenčiny - v nárečiach, ale ani $\mathrm{v}$ jeho spisovnej podobe nepozná význam slov šur, dever, svojak, zolva, jetrva. Pôvodný domáci prvok bol vystavený napätiu, externému tlaku, ktorý spôsobili dva formotvorné elementy: krestanstvo (christianitas) a spoločenstvo (communitas), ktoré sa podla Nade Rácovej (Rácová 2004) prejavili ako ovela dôležitejšie, než akými boli individuálne pokrvné zväzky a etnicita so svojím primárnym atribútom - jazykom. V takomto jazykovo, kultúrne či duchovne heterogénnom prostredí spoločenstvo používatelov jazyka výrazne znižovalo individuálny pocit aliterity jednotlivca a harmonizovalo ho so svojím okolím. Významová skupina nomina afinitatis poukazuje na tendencie, ktorými je slovenčina na jednej strane svedectvom najstarších vonkajších interkultúrnych vplyvov na slovansko-neslovanskom etnickom pomedzí a aj 
dôkazom narúšania delimitačného stereotypu. Na druhej strane sa adaptáciou nových výrazov a zjednodušením vnútornej pomenovacej štruktúry pôvodných vzt̉ahov prejavuje rovnaká miera vonkajšieho tlaku na západoslovanskú skupinu jazykov, ktorá sa vývinovo prejavila ako širší jazykovo aj geneticky nerovnorodý areál. Zmeny, zaregistrované $\mathrm{v}$ ňom sa riadili aj riadia všeobecne platným zákonom rozumu, zasahujúcim vnútorné postoje človeka k svojmu kultúrnemu a mentálnemu prostrediu. A tak sa aj jednotlivé zväzky Slovanského jazykového atlasu a na ne nadväzujúce monografie J. Siatkowského stávajú presvedčivým výrazom prínosu dialektológa, slavistu a historického jazykovedca do metodológie lingvistického bádania a integrácie jeho výsledkov s ostatnými spoločenskovednými disciplínami.

\section{Bibliografia}

Majtán Milan (red.), 1991, Historický slovník slovenského jazyka, t. 1, Bratislava.

Rácová Nada, 2004, O vztahu individuálnej identity jednotlivca a jeho príslušnosti $\mathrm{k}$ spoločenstvu, „Slavica Slovaca“, t. XXIV, Bratislava, s. 124-131.

Siatkowski Janusz, 2004, Studia nad wpływami obcymi w Ogólnosłowiańskim atlasie jezykowym, Warszawa.

Siatkowski Janusz, 2005, Słowiańskie nazwy wykonawców zawodów w historii i dialektach, Warszawa.

Siatkowski Janusz, 2012, Słowiańskie nazwy części ciała w historii i dialektach, Warszawa. Siatkowski Janusz, 2015, Studia nad słowiańsko-niemieckimi kontaktami językowymi, Warszawa.

Žigo Pavol, 2010, Pomenovanie rodinných vztahov v slovenčine z hladiska etnokultúrnej identity, „Studia Academica Slovaca“, t. XXXIX, Bratislava.

Žigo Pavol, Žigová Ludmila, 1987, Vyjadrenie príbuzenských vztahov v slovenčine a ruštine. „Ruštinár“, t. XXII, Bratislava.

\section{Streszczenie}

Interpretacja elementów leksykalnych - nazw członków rodziny (słowiańskie nomina afinitatis - šur, dever, svojak, zolva/zelva, jetrva vs. germanizm švagor/švagr/šogor/szwagier, italianizm kuňot lub turcyzm kadžinbirader > kainč) - służy ukazaniu zmian oraz zasięgów tych leksemów w dialektach słowackich i językach słowiańskich. Wybrane zjawiska na terytorium słowackim i słowiańskim są omówione na podstawie materiałów do Ogólnosłowiańskiego atlasu językowego - ważnego projektu dialektologii słowiańskiej i geografii lingwistycznej - z wykorzystaniem 3454 pytań i siatki 853 punktów miejscowych państw słowiańskich środkiem interpretacji interkulturalnej i międzyjęzykowej (szczegółowe informacje: http://slavatlas.org). 